1973 mayoral race and chapter six, which goes into great detail about the Panther's foray into real politick as well as the Panther's array of survival programs, for which they are perhaps least known, but nevertheless enabled them to perhaps make their greatest impact.

The least interesting aspect of the book is the discussion of the BPP's demise. A good deal has been written about state repression of the BPP and the author provides little, if any, new information on this score. Much has also been made, recently, of the lack of democracy within the Party and its eroding affect. The argument that the absence of democratic mechanisms within the Party contributed greatly to its downfall is parsimonious and to a large degree, overstated. Like all forms of government, Democracy has its limitations. It should be noted that Democracy is not featured prominently within the United States military, an institution on which the Panthers modeled their organizational hierarchy as well as many other often unacknowledged trappings. Also, Mao Tse Tung, someone whose works and deeds influenced the Panthers immensely was not an advocate of democracy. Given these strong influences the kind of strong democratic apparatus that exists within many organizations was not likely to occur within the Black Panther Party.

Living For the City is a fine addition to the literature on the BPP, the Black Power Movement and Black life in Oakland generally. While some readers will find that Murch reiterates a fair amount of material about the BPP that is already known what is undeniable is that the book also excavates a fair amount of new material as well as presents information from angles and points of view that have heretofore gone unexplored. The book could have benefitted from a closer editing. And like many books that feature the BPP, a few statements are made with more vigor than basis of fact. Nevertheless, Living For the City is a well crafted and rigorously researched text that makes a strong contribution to the literature.

Judson L. Jeffries

The Ohio State University

Donald W. Rogers, Making Capitalism Safe: Work Safety and Health Regulation in America, 1880-1940 (Urbana and Chicago: University of Illinois Press, 2010).

Donald Rogers's Making Capitalism Safe: Word Safety and Health Regulation in America, 1880-1940 is a critique of the historiographical interpretation of the Progressive Era in the United States that represents regulatory reform in the late nineteenth and early twentieth centuries as controlled or predominantly shaped 
by the giant corporations that ruled the industrial landscape. But, Rogers asks, how can this be reconciled with the view of such iconic reformers as John R. Commons who hail the work of the Wisconsin Industrial Commission (and a few others similar agencies) as having "saved Capitalism by making it good." (3) Was labour law reform in the US, therefore, an expression of the ideology and influence of big business or was it the result of independent and truly progressive state regulation?

The author makes a strong case for the argument that Wisconsin's Industrial Commission was an effective, unusual, and modern force for reform, not only at the beginning of the twentieth century, but also well into the middle years of the century. The commission was signed into law on 30 June 1911, two months after the horrendous Triangle Shirtwaist Factory Fire in which 146 garment workers died, most of them young women who either suffocated or jumped to their deaths to escape the flames. Unlike other states's efforts, the Wisconsin Commission was "composed of impartial administrators, rather than interest-group representative" (67), that had a broad based agenda and purview: workers compensation, safety laws, protective legislation for women, child labour laws, and industrial arbitration, among others. Rather than relying on the state legislature to enact specific legislation or waiting for workers to force businesses to change their practices because of individual lawsuits, these areas of labour law and regulation were addressed through administrative rules that the commission adopted. It also established the principle of business's obligation to provide a "safe place" for people to work, rather than the much more business friendly common law principle of "due care." Rogers argues that because the commission operated outside of the framework of interest group politics, it could use its "code making proceedings to serve state goals," specifically, "social stability and economic prosperity" (84). Even during the heyday of business domination and conservative politics of the 1920s, the author shows that the commission was able to have a critical impact on making businesses behave more responsibly in Wisconsin, and to reduce accidents in the state. All in all, Rogers maintains, the Industrial Commission adopted "a 'left corporate liberal' technocratic approach to safety and health regulation" that was highly effective in both "reducing industrial hazards and securing industrial peace" (173).

Rogers makes an important contribution by emphasizing the importance of the Wisconsin experience but, while he raises the commission's similarities to the European models, he does not develop this idea and explain why it is significant. Parallels to the experience of several European countries are critical because, in addition to the social democracies of Scandinavia, one could argue that nations such as Germany and France, by adopting the administrative state apparatus for dealing with work injuries and illnesses, have more successfully limited assaults on workers than the United States has done.

More importantly, Rogers, in this reviewer's estimation, overemphasizes 
the Wisconsin Commission's importance for understanding reform within the US over the course of the twentieth century. He acknowledges that even more progressive states, such as New York, Illinois, and California, adopted only parts of the Wisconsin model, and that workers in the vast majority of states were provided with far less protection and support than that provided by Wisconsin. While he is undoubtedly correct that historians have erred in seeing Wisconsin and a few other states' institutions as "weak" or "spare," he does not present the evidence that would support the notion that the majority - or even a substantial minority - of the states had institutions or programs that came close to achieving what Wisconsin's did. Indeed, while the author provides a strong account of the forces that accounted for the success of the Wisconsin Industrial Commission, he does not present a strong analysis of the class and political forces that caused other states' programs to be inferior. For example, in an effort to show that occupational disease coverage in workers compensation legislation was more prevalent than other historians (including this reviewer) have acknowledged, the author overreaches and fails to acknowledge the critical role that labour and reformers played in securing such legislation.

Finally, Rogers, perhaps in his enthusiasm for the Wisconsin model, seems to regret the passing of states initiatives that resulted from the establishment of the federal Occupational Safety and Health Administration (OSHA) in 1970. While he acknowledges that none of the states sought to achieve OSHA's goal of insuring that employers provide workers with employment "free from recognized hazards" (180), he judges that federal regulation itself has largely not lived up to its "idealistic" and "laudable" goals. This, he posits, was not only because of the "conservative political environment" that almost immediately followed the establishment of OSHA, but also because of the "administrative complexity" of the agency itself (181). This is not an adequate analysis of the assault that OSHA was under virtually from its creation, and Rogers does not provide any evidence that state programs would have fared any better if they had been truly committed to protecting the workers in their jurisdictions.

Gerald Markowitz

John Jay College and Graduate Center, CUNY

\section{Mark Reinhardt, Who Speaks for Margaret Garner? The True Story that Inspired Toni Morrison's Beloved (Minneapolis: University of Minnesota Press, 2010).}

I became acquainted with Margaret Garner and her family during the mid-1980s while doing research for my dissertation. Since then, I have included snippets of her story in various publications. Given my familiarity with the Garner saga, this 